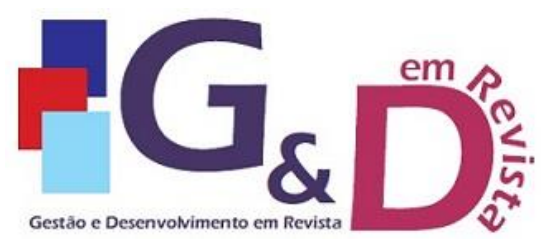

\title{
CARACTERIZAÇÃO DOS ESTABELECIMENTOS AGROPECUÁRIOS E POPULAÇÃO OCUPADA: UMA ANÁLISE PARA CHAPECÓ, MARAVILHA E SÃO LOURENÇO DO OESTE- SC ${ }^{1}$
}

\author{
Tatiane Salete Mattei \\ Doutoranda no Programa de Pós-Graduação em Desenvolvimento Regional e Agronegócio (PGDRA) \\ da UNIOESTE Campus Toledo-PR. \\ E-mail: tatianemattei.slo@gmail.com \\ Ricardo Rippel \\ Doutor em Demografia pela Universidade Estadual de Campinas - UNICAMP. Atualmente é \\ professoa associada da Universidade Estadual do Oeste do Paraná - UNIOESTE. \\ E-mail: ricardorippel@yahoo.com.br
}

\section{Resumo}

A agropecuária é um setor relevante para o crescimento e desenvolvimento econômico brasileiro. $O$ estado de Santa Catarina ocupa posição importante no cenário nacional na produção de suínos, frangos e pecuária leiteira, com destaque para a mesorregião Oeste. $O$ trabalho se propôs a caracterizar os estabelecimentos agropecuários e a população rural ocupada de três municípios notórios em população e produção agropecuária de uma das principais microrregiões da mesorregião Oeste, a microrregião de Chapecó. Os dados foram extraídos dos Censos Agropecuários de 2006 e 2017. Os principais resultados mostram que o número de estabelecimentos e população rural ocupada vem se reduzindo no período nos três municípios, o que também é uma tendência nacional. Nesses municípios são encontrados na maior parte pequenos estabelecimentos, familiares, fruto do processo de colonização de minifúndios da mesorregião Oeste. Se percebeu que os jovens de até 25 anos são minoria no campo, com participação decrescente no período. A escolarização da população rural ainda é um gargalo, assim como a geração de renda das pequenas propriedades.

Palavras-chave: Agropecuária; população ocupada; estabelecimentos rurais.

\begin{abstract}
Agriculture is a relevant sector for Brazilian economic growth and development. The state of Santa Catarina occupies an important position in the national scenario in the production of swine, chicken and dairy, with emphasis on the western mesoregion. The work aimed to characterize the agricultural establishments and the rural population employed in three municipalities notorious for population and agricultural production in one of the main microregions of the western mesoregion, the microregion of Chapecó. Data were taken from the 2006 and 2017 Agricultural Censuses. The main results show that the number of establishments and employed rural population has been decreasing in the period in the three municipalities, which is also a national trend. These municipalities are mostly small, family-run establishments, as a result of the colonization process of smallholdings in the western mesoregion. It was noticed that young people up to 25 years old are a minority in the countryside, with decreasing participation in the period. The schooling of the rural population is still a bottleneck, as is the generation of income on small properties.
\end{abstract}

Keywords: Agriculture; employed population; rural establishments.

\footnotetext{
${ }^{1}$ Artigo apresentado no IX Congresso Nacional de Pesquisa em Ciências Sociais Aplicadas - Conape e publicado nos anais do respectivo Congresso e aprovado para publicação nessa Revista pelo sistema Fast-Track.
} 


\section{INTRODUÇÃO}

$\mathrm{Na}$ década de 1960 a agricultura brasileira passou por um processo considerado divisor de águas. A chamada Revolução Verde, que no âmbito mundial surgiu para solucionar o problema da fome, reconfigurou o espaço rural (SANTOS, 2020). A diversificação da produção para o mercado interno foi estimulada através de políticas públicas, assim como investimentos em pesquisas agrícolas buscando aumento da produtividade com o uso de técnicas modernas, máquinas, insumos, sementes adaptadas e adubos químicos (CORRÊA; LIMA, 2016).

O progresso técnico possibilitou aumento da produção e produtividade agroalimentar, aumentando a concorrência e reduzindo preços. Em contrapartida, os produtores que não conseguiram se adequar ao pacote tecnológico, majoritariamente os de baixa renda, com poucas terras e sem acesso ao crédito foram forçados a deixar a produção, investir em trabalhos alternativos ou se manter no campo em situação de vulnerabilidade (SANTOS, 2020).

O processo de modernização do campo brasileiro é chamado de conservador, marcado por aumento de escala e produtividade, mas com profundas assimetrias entre os diversos tipos, tamanhos de produtores e regiões. A renovação tecnológica ocorreu sem que a estrutura agrária concentradora fosse alterada (GARCIA, 2014).

A modernização tecnológica produziu também alterações nas oportunidades de ocupação e trabalho. O assalariamento rural tem diminuído e a sazonalidade da demanda aumentado em virtude do aumento da mecanização. Além disso, a atratividade dos empregos urbanos tem contribuído para a massiva migração rural. Paralelo a isso tem-se também a escassez de mão de obra e o aumento das exigências quanto a escolaridade dos produtores (BUAINAIN et al., 2014).

A baixa qualificação dos trabalhadores interfere negativamente na agricultura, pois reduz o poder de barganha, reduz remunerações e leva a condições precárias de trabalho (GARCIA, 2014). Informação e conhecimento se tornam necessários para o agricultor poder competir no mundo contemporâneo. O agricultor precisa conhecer as tecnologias e discernir qual é a mais adequada, precisa saber comprar e vender, realizar contratos, gerir recursos humanos, gerir o tempo e tomar 
decisões intempestivas dada a característica de muitos riscos da atividade (BUAINAIN, 2014).

Um risco social que a agricultura vem enfrentando, principalmente a agricultura familiar predominante no país, é a migração sobretudo dos membros mais jovens das famílias e das mulheres, o que levanta o problema da sucessão familiar no campo. A principal causa desse movimento são os problemas na geração de renda insuficiente para o sustento dos membros da família (KIYOTA; PERONDI, 2014).

Apesar das contradições e riscos, a agropecuária brasileira exerce papel importante na dinâmica econômica, seja por assumir papel anticíclico, pois historicamente tem apresentado altos volumes de exportações mesmo em períodos de crise, resultando em saldos comerciais superavitários e crescentes, seja na geração de emprego e renda e no controle do êxodo rural (GARCIA, 2014; SANTOS et al., 2016). Segundo o Censo agropecuário de 2017, 15 milhões de pessoas estão ocupadas no meio rural, sendo $80,9 \%$ pertencentes a agricultura familiar. Em Santa Catarina esse número é de pouco mais de 500 mil pessoas, sendo $72,5 \%$ na agricultura familiar.

Com o crescimento populacional, se torna função básica da agropecuária o fornecimento de alimentos. Quando os preços dos alimentos são elevados, há implicação no aumento dos salários, que por sua vez causa aumento dos custos de produção e a redução de lucros, diminuindo assim o ritmo de desenvolvimento econômico. Outras funções importantes da agricultura e pecuária são o fornecimento de capital para a expansão do setor não agrícola, divisas para a compra de insumos e bens de capital, mercado consumidor para os produtos não agrícolas, fornecedor de matéria prima para o setor produtivo e liberação de mão de obra para indústria em decorrência do processo de mecanização das atividades agrícolas (BACHA, 2012).

O Brasil passou de importador de alimentos básicos na década de 1960 para exportador a partir de 1980 e o estado de Santa Catarina ocupa posição de destaque no cenário nacional em alguns produtos. Em 2018 a produção de suínos foi a maior dentre os estados e a carne de frango ficou na segunda posição. $O$ estado também se destaca na produção de leite, sendo o quarto maior com participação dentre os estados. 
O objetivo do trabalho é caracterizar os estabelecimentos agropecuários e a população ocupada, a partir de uma análise comparativa realizada com os dados disponíveis no Censo Agropecuário dos anos de 2006 e 2017. Os objetos de análise são três principais municípios da microrregião de Chapecó pertencentes a Mesorregião Oeste de Santa Catarina: Chapecó, Maravilha e São Lourenço do Oeste. O Censo agropecuário foi escolhido por apresentar informações completas e riquíssimas sobre o meio rural brasileiro.

Dentro de Santa Catarina a Mesorregião Oeste é uma das mais importantes. Ela participou com $80,53 \%$ da produção catarinense de frangos e por $78,57 \%$ dos suínos produzidos em 2019 (EPAGRI/CEPA, 2020). Uma das microrregiões do Oeste, a Microrregião de Chapecó ocupa papel destaque na produção de milho, trigo e soja.

Os objetos de análise foram escolhidas levando em consideração a relevância na produção agropecuária, além do fato de serem as cidades mais populosas da microrregião são Chapecó (IBGE, 2017).

A agropecuária é um setor da economia que está em constante desenvolvimento e vem contribuindo consideravelmente para o crescimento do PIB brasileiro. Devido a relevância desse segmento faz-se necessário conhecer o perfil dos trabalhadores rurais que estão contribuindo com esses resultados, assim como as características dos estabelecimentos e qual a atividade predominante nos municípios (ARRAIS; PRAT; CAMBRAIA, 2019).

Inicialmente foram coletadas informações para caracterizar socioeconomicamente os três municípios, com informações sobre sua história para contextualizá-los perante sua importância na microrregião a que pertencem e ao Estado. Após isso, foram coletadas informações divulgadas pelos Censos Agropecuários e tratadas com ajuda do Microsoft Excel. As variáveis selecionadas constam nos dois anos dos Censos Agropecuários, sendo as que caracterizam os estabelecimentos relacionadas a quantidade, área, valor da produção, participação da agricultura familiar, condição do produtor em relação as terras, composição da lavoura temporária e produtividade. As informações relacionadas ao valor foram deflacionadas em relação ao INPC e considerado o ano de 2017 como ano base.

Além disso, para caracterizar a população ocupada no meio rural foram apresentadas informações a respeito do sexo, laço de parentesco, idade do 


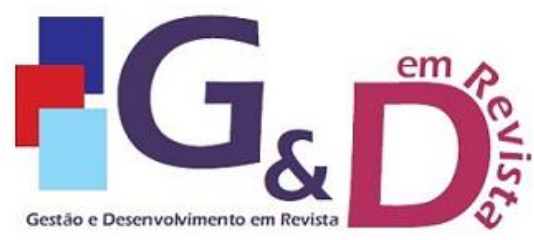

Gestão e Desenvolvimento em Revista V. 8, N. 2, jul-dez/2021, p. 42-67.

ISSN online: $2446-8738$

Artigo recebido em: 21/10/2021

Artigo aprovado em: 12/11/2021

dirigente, escolaridade do dirigente, recebimento de orientação técnica e associação em cooperativas ou entidades de classes.

\section{CARACTERIZAÇÃO DOS OBJETOS DE ANÁLISE}

Santa Catarina é um estado brasileiro, localizado na região Sul do Brasil, que possui 295 municípios e aproximadamente 7,2 milhões de habitantes (IBGE, 2020). O estado ocupa posição de destaque no cenário nacional na produção de suínos e frangos. Em 2018 participou com 26,63\% da produção nacional de carne suína, sendo o maior estado produtor do Brasil e participou com 13,85\% na produção de carne de frango, sendo o segundo maior produtor brasileiro. expressivo desenvolvimento dessas atividades está ligado ao mercado externo, sendo a China o maior consumidor (EPAGRI/CEPA, 2020).

$O$ estado também se destaca na produção de leite, sendo o quarto maior com participação de 9,3\% da produção brasileira (EPAGRI/CEPA, 2020). A atividade leiteira tem importância social significativa. A produção é realizada na maioria das vezes em pequenas propriedades, transformando a atividade no principal pilar da agricultura familiar, em especial na mesorregião Oeste do estado de Santa Catarina, onde prevalece essa produção (JOCHIMS; DORIGON; PORTES, 2016).

Embora a agropecuária de Santa Catarina seja bastante diversificada, frango, suínos e leite respondem por cerca de $46 \%$ do Valor Bruto da Produção. No total 7 produtos (além desses soja, tabaco, bovinos e milho) respondem por $73,2 \%$ da produção do estado. Nos últimos anos a produção de frangos e de tabaco vem perdendo participação, a de suínos e a de soja aumentando (EPAGRI/CEPA, 2020).

A mesorregião Oeste de Santa Catarina foi a última do estado a ser colonizada, e dentre a região, a microrregião do extremo oeste foi a última, no início do século XX. A colonização ocorreu com a vinda de descendentes de imigrantes italianos, alemães e poloneses provenientes principalmente do Rio Grande do Sul por um movimento induzido pelo governo catarinense. A região já era ocupada por índios, bugres e caboclos. O que atraiu a população imigrante para a região foi a extração da madeira e erva mate (FRIESTINO; BALDISSERA; SANTOS, 2020).

As terras do Oeste de Santa Catarina foram colonizadas sob um modelo de minifúndio, onde cada filho dos agricultores normalmente recebia ou comprava um 
lote de terra do tamanho proporcional ao que a família possuía. A produção agropecuária se baseou na diversificação com cultivo de produtos básicos, como feijão, arroz e milho, e criação de animas como suínos e aves para o consumo. Essa estrutura agrária em pouco tempo se modernizou e possibilitou o desenvolvimento das agroindústrias catarinenses, que cresceram baseadas no sistema de integração agroindustrial (ALVES; MATTEI, 2006).

Referente a uma das principais culturas vegetais brasileiras, a soja, Santa Catarina se destaca pela alta produtividade. O rendimento médio dessa cultura na safra 2018/2019 foi de $3.637 \mathrm{~kg} / \mathrm{ha}$, bem superior à média nacional, que é de $3.162 \mathrm{~kg} / \mathrm{ha}$, colocando o Estado no primeiro lugar em produtividade dentre os principais produtores. A tecnologia adotada pelas pequenas propriedades, similar às grandes propriedades, apoiada por assistência técnica de cooperativas, pesquisa e extensão rural é que faz com que os produtores alcancem bons resultados (EPAGRI/CEPA, 2020).

A agricultura familiar de Santa Catarina é inserida nas principais cadeias produtivas e também integrada à rede de serviços bancários, presente em todos os municípios. Além disso, conta com a forte presença do serviço público de extensão rural, particularmente com a Epagri, também atuante em todos os municípios. Outros fatores que contribuem para que a agricultura familiar catarinense seja integrada são os conselhos municipais de desenvolvimento rural, o movimento sindical e cooperativista, com trabalhos de mobilização e comunicação junto aos agricultores. Santa Catarina contou com $67,15 \%$ das operações de crédito rural via Pronaf em 2018, ficando na frente de PR e RS e em âmbito nacional ficando em segundo lugar (EPAGRI/CEPA, 2020).

A mesorregião Oeste Catarinense foi responsável por $80,53 \%$ da produção catarinense de frangos em 2019 e por $78,57 \%$ dos suínos produzidos. O Oeste Catarinense é composto por 05 (cinco) microrregiões: Chapecó, Concórdia, Joaçaba, São Miguel do Oeste e Xanxerê, que conjuntamente abrangem 109 municípios, que representa $40 \%$ do número de municípios do Estado. O Oeste é uma região que abriga $20 \%$ da população total e $34 \%$ da população rural de Santa Catarina. A microrregião de Chapecó é uma das mais importantes, participando com $17,30 \%$ da produção de suínos e $21,60 \%$ das aves produzidas no estado (EPAGRI/CEPA, 2020). 


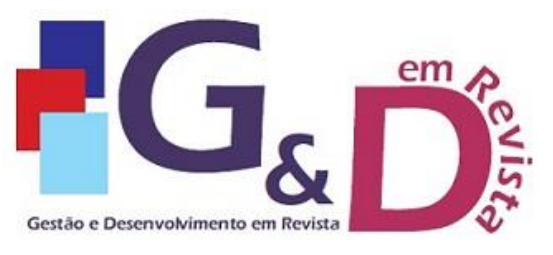

Gestão e Desenvolvimento em Revista V. 8, N. 2, jul-dez/2021, p. 42-67. ISSN online: $2446-8738$

Artigo recebido em: 21/10/2021

Artigo aprovado em: 12/11/2021

Apesar da ocupação no século XX, a mesorregião Oeste só apresentou crescimento populacional significativo a partir de 1970 , participando com $26,3 \%$ da população nesse ano, mas reduzindo nas décadas seguintes, fruto da migração de parte da população para outras regiões (ALVES; MATTEI, 2006). A microrregião de Chapecó tem 38 municípios que possuem uma população total de 434.575 habitantes (ano-base: 2015) (IBGE, 2017).

A Microrregião de Chapecó ocupou a primeira posição dentre as microrregiões do Estado em quantidade produzida de milho (18,35\% da produção do Estado), segunda de trigo (20,8\%) e quarta de soja (10,7) em 2017 (IBGE, 2017). Dentre os municípios mais relevantes na produção agrícola dessa microrregião em 2017, Campo Erê participou com 10,32\% da quantidade produzida de milho, Palmitos com 7,80\% e Quilombo com 7,78\%; Na soja, Campo Erê participou com $22,60 \%$ da produção total da microrregião, Chapecó com 9,56\% e São Lourenço do Oeste com 5,39\%. Na quantidade produzida de trigo, Campo Erê participou com $24,77 \%$ da produção da microrregião, Cunha Porã com 11,51\% e Maravilha com 9,79\% (IBGE, 2017).

O artigo se propõe a analisar os municípios de Chapecó, Maravilha e São Lourenço do Oeste. Na Figura 1 é apresentada a localização desses municípios.

Figura 1- Localização dos municípios de análise

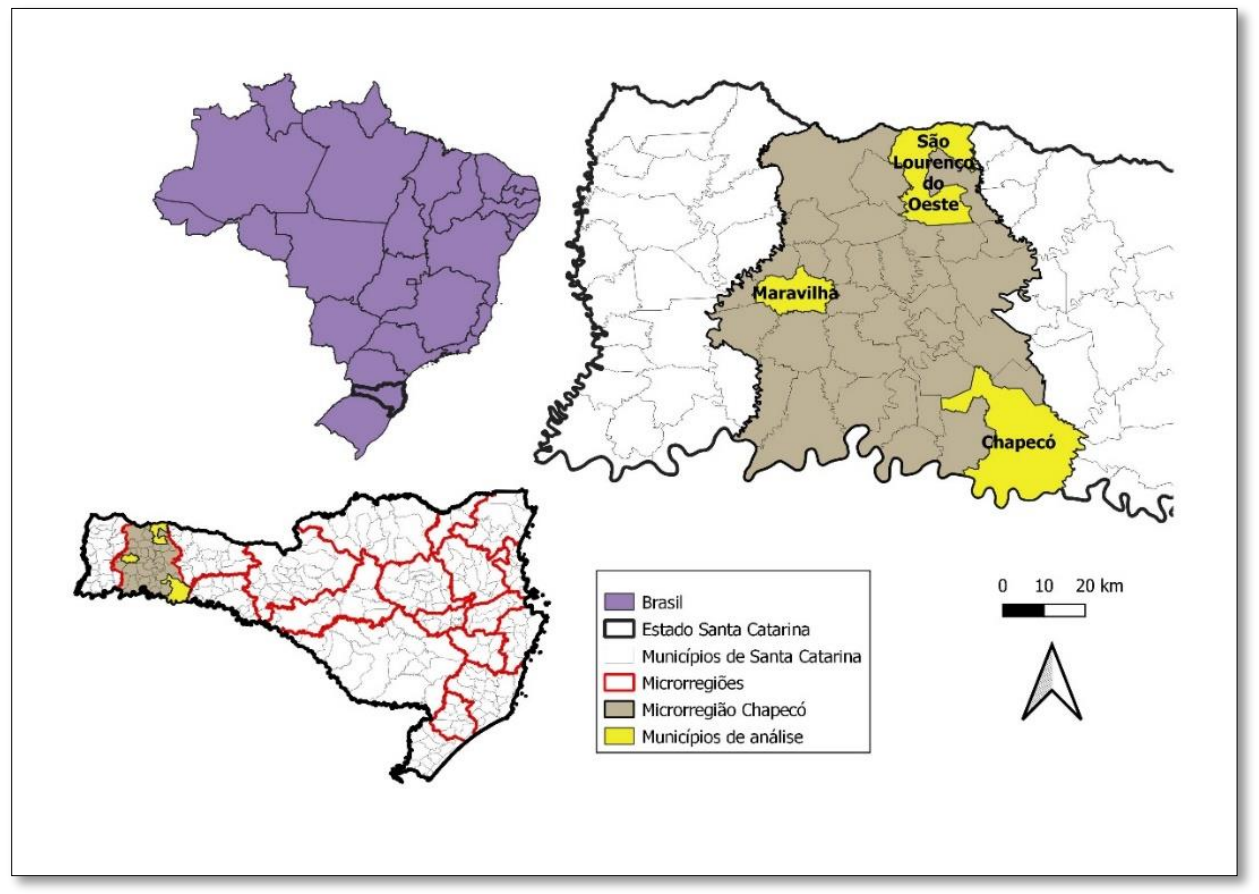

Fonte: elaborado pelos autores. 


\section{INFORMAÇÕES SOCIOECONÔMICA DOS MUNICÍPIOS}

De acordo com estimativas do IBGE para 2020, cerca de $56 \%$ dos municípios do Oeste de Santa Catarina apresentam população inferior a 5.000 habitantes. A cidade de Chapecó responde por aproximadamente $17 \%$ da população da mesorregião Oeste e de $65 \%$ da microrregião de Chapecó e foi o município que mais recebeu migrantes no período de 2000-2004, cerca de 50\% do fluxo migratório do Oeste (IBGE, 2020; ALVES; MATTEI, 2006).

Chapecó é um polo regional e um importante centro receptor de investimentos nos complexos transformadores dos agronegócios (carnes e grãos) e no setor imobiliário-empresarial. Abriga as principais agroindústrias da mesorregião sendo elas a BRF-Brasil Foods S. A., a Cooperativa Central Aurora e a Cooper Alfa. Essas empresas são destaques no comércio internacional de alimentos e responsáveis por dotar a região Oeste de uma dinâmica particular (DENTZ, 2019; VARNIER, 2020).

Segundo o Índice Firjan de Desenvolvimento Municipal, Chapecó teve crescimento considerável deste indicador em uma década $(0,8125$ para 0,8684$)$ e atualmente apresenta o $2^{\circ}$ maior indicador do estado e $\circ 25^{\circ}$ dentre todos os mais de 5 mil municípios brasileiros.

Chapecó é responsável por aproximadamente $53 \%$ do PIB da microrregião e $3,21 \%$ do PIB do Estado. O setor de serviços é o mais expressivo referente ao Valor Adicionado Bruto (VAB), muito em decorrência dos serviços ligados a agropecuária e agroindústrias. Outros serviços que expressam a centralidade de Chapecó perante a região é o automotivo, comércio varejista, serviços ligados ao aeroporto e comércio de bens de consumo em geral (DENTZ, 2019).

$\mathrm{Na}$ Tabela 1 é apresentado uma síntese de informações socioeconômicas do município de Chapecó. 


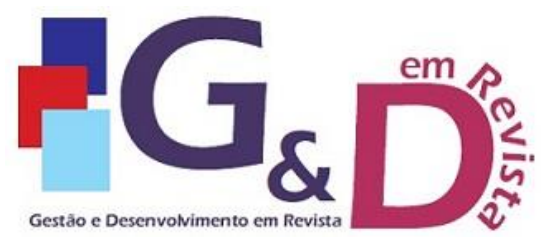

Gestão e Desenvolvimento em Revista V. 8, N. 2, jul-dez/2021, p. 42-67.

ISSN online: $2446-8738$

Artigo recebido em: 21/10/2021

Artigo aprovado em: 12/11/2021

Tabela 1- Informações socioeconômicas de Chapecó-SC

\begin{tabular}{|c|c|c|}
\hline Data de emancipação & \multicolumn{2}{|c|}{25 de agosto de 1917} \\
\hline Área & \multicolumn{2}{|c|}{$624.846 \mathrm{~km}^{2}$} \\
\hline População & $183.530(2010)$ & 224.013 ( 2020) \\
\hline Percentual população rural & \multicolumn{2}{|c|}{$8,4 \%(2010)$} \\
\hline IFDM & $0,8125(2006)$ & $0,8684(2016)$ \\
\hline Ranking IFDM & $144^{\circ}$ Brasil e $17^{\circ} \mathrm{SC}$ & $25^{\circ}$ Brasil e $2^{\circ} \mathrm{SC}$ \\
\hline PIB em mil reais & $4.651 .907(2006)$ & $8.893 .190(2017)$ \\
\hline $\begin{array}{l}\text { Participação do PIB no PIB da } \\
\text { microrregião e do Estado }\end{array}$ & 44,36 e 2,69 (2006) & 53,01 e $3,21(2017)$ \\
\hline $\begin{array}{l}\text { Participação VAB agropecuária, } \\
\text { indústria, serviços, administração } \\
\text { pública }\end{array}$ & $\begin{array}{c}3,92 ; \quad 28,23 ; 54,41 ; 13,44 \\
(2006)\end{array}$ & $\begin{array}{c}1,85 ; 26,20 ; 59,49 ; 12,46 \\
(2018)\end{array}$ \\
\hline PIB per capita & \multicolumn{2}{|c|}{$44.321,07(2018)$} \\
\hline $\begin{array}{l}\text { Salário médio dos trabalhadores } \\
\text { formais }\end{array}$ & \multicolumn{2}{|c|}{ 2,8 salários (2018) } \\
\hline Taxa de mortalidade infantil & $12,82(2006)$ & $11,09(2017)$ \\
\hline Esperança de vida & $73,40(2000)$ & $77,25(2010)$ \\
\hline Razão de dependência & $51,40(2000)$ & $38,45(2010)$ \\
\hline Taxa de fecundidade & $2,34(2000)$ & $1,82(2010)$ \\
\hline Taxa de analfabetismo & $6,7(2000)$ & $4,7(2010)$ \\
\hline IDEB anos iniciais & $4,5(2005)$ & $6,4(2019)$ \\
\hline IDEB anos finais & $3,9(2005)$ & $4,9(2019)$ \\
\hline IDEB ensino médio & $3,8(2017)$ & $4,1(2019)$ \\
\hline
\end{tabular}

Fonte: IBGE, 2010; 2017; 2020. FIRJAN, 2020 e INEP, 2020.

Nota: PIB deflacionado com base INPC a preços de 2017.

Maravilha é o segundo maior município em população da microrregião de Chapecó e o décimo da mesorregião Oeste segundo estimativas do IBGE para 2020. Fica localizado a $86 \mathrm{~km}$ de Chapecó e $618 \mathrm{~km}$ da capital Florianópolis e é cortado pelo entroncamento de duas importantes rodovias nacionais (BRs $282 \mathrm{e}$ 158). Sua economia é baseada na agropecuária, indústria, com destaque para a moveleira e serviços, esse muito ligado também ao setor agropecuário (GEREl, 2019).

De acordo com IFDM, o município praticamente manteve o valor do seu indicador de 2006 para 2016, mas perdeu posição em relação a sua colocação no ranking no país e no estado. Dentre os 3 municípios analisados, Maravilha apresenta maior PIB per capita, menor taxa de mortalidade infantil e maior esperança de vida.

Na Tabela 2 é apresentado uma síntese das informações socioeconômicas do município de Maravilha. 
Tabela 2- Informações socioeconômicas de Maravilha-SC Data de emancipação

\begin{tabular}{|c|c|c|}
\hline 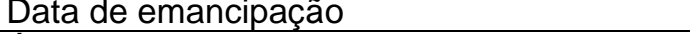 & \multirow{2}{*}{\multicolumn{2}{|c|}{170.339}} \\
\hline Área & & \\
\hline População & $22.101(2010)$ & 26.116 ( 2020) \\
\hline Percentual população rural & \multicolumn{2}{|c|}{$18,16(2010)$} \\
\hline IFDM & $0,8260(2006)$ & $0,8264(2016)$ \\
\hline Ranking IFDM & $102^{\circ}$ Brasil e $8^{\circ} \mathrm{SC}$ & $195^{\circ}$ Brasil e $18^{\circ} \mathrm{SC}$ \\
\hline PIB em mil reais & $667.770(2006)$ & $1.055 .389(2017)$ \\
\hline $\begin{array}{l}\text { Participação do PIB no PIB da microrregião } \\
\text { e do Estado }\end{array}$ & 6,37 e 0,39 (2006) & 6,29 e $0,38(2017)$ \\
\hline $\begin{array}{l}\text { Participação VAB agropecuária, indústria, } \\
\text { serviços, administração pública }\end{array}$ & $\begin{array}{l}4,94 ; \quad 43,21 ; 41,64 ; \\
10,21(2006)\end{array}$ & $\begin{array}{l}3,76 ; 39,58 ; 45,80 ; \\
10,86(2018)\end{array}$ \\
\hline PIB per capita & \multicolumn{2}{|c|}{$50.727,80(2018)$} \\
\hline Salário médio dos trabalhadores formais & \multicolumn{2}{|c|}{2,2 salários $(2018)$} \\
\hline Taxa de mortalidade infantil & $3,48(2006)$ & $2,78(2017)$ \\
\hline Esperança de vida & $74,16(2000)$ & $78,17(2010)$ \\
\hline Razão de dependência & $51,97(2000)$ & $40,92(2010)$ \\
\hline Taxa de fecundidade & $2,24(2000)$ & $1,53(2010)$ \\
\hline Taxa de analfabetismo & $6,7(2000)$ & $4,9(2010)$ \\
\hline IDEB anos iniciais & $4,2(2005)$ & $6,3(2019)$ \\
\hline IDEB anos finais & $4,4(2005)$ & $4,8(2019)$ \\
\hline IDEB ensino médio & $4,0(2017)$ & $4,6(2019)$ \\
\hline
\end{tabular}

Fonte: IBGE, 2010; 2017; 2020. FIRJAN, 2020 e INEP, 2020.

Nota: PIB deflacionado com base INPC a preços de 2017.

Por fim, São Lourenço do Oeste é o terceiro maior município em população da microrregião de Chapecó e o décimo primeiro da mesorregião Oeste segundo estimativas do IBGE para 2020. Faz divisa ao Norte com o Estado do Paraná, fica a 108 quilômetros de Chapecó, 87 de Maravilha e 643 da capital Florianópolis. Na indústria se destaca o ramo alimentício de biscoitos e massas, em que abriga duas grandes empresas Nutrisul/Casaredo e a Parati, essa agora incorporada a multinacional Kellogs. A cidade é conhecida como a capital das massas e biscoitos. Predomina a agricultura familiar com destaque para a produção leiteira, de suínos e aves em sistema de integração e cooperativismo. No setor de serviços se destaca serviços de apoio a construção civil.

O município deu um salto de desenvolvimento nos últimos anos, passando da posição $32^{\circ}$ para $7^{\circ}$ no ranking estadual do IFDM. Se destaca também na nota do IDEB, indicador que avalia a qualidade da educação. Alcançou em 2019 nota 7 nos anos iniciais da educação básica, numa escala de 0 a 10 , dentre os maiores do Estado, também melhorando consideravelmente desde 2006.

Dentre os três municípios analisados, São Lourenço do Oeste apresenta a maior razão de dependência. Valores altos desse indicador sugerem que a população em idade ativa (entre 15 e 59 anos) sustenta uma grande proporção de 
dependentes (menores de 15 e maiores de 60 anos), o que significa envelhecimento da população e maiores gastos assistências para a sociedade com os idosos e crianças. Esse indicador se reduziu para os 3 municípios analisados no período. $O$ indicador do Brasil era de 54,88 para os anos 2000 e também reduziu, passando para 45,87 em 2010. O decréscimo desse indicador está relacionado a queda dos níveis de fecundidade, percebidos nos 3 municípios e também para o Brasil, que passou de 2,37 em 2000 para 1,89 em 2010. A taxa de fecundidade ideal seria acima de 2,1 para equiparar as idades das populações e repor a força produtiva. A redução da taxa de fecundidade leva a diminuição das taxas de natalidade, implicando num decréscimo do contingente jovem da população, a população idosa, portanto, experimenta elevação de sua participação relativa e absoluta.

$\mathrm{Na}$ Tabela 3 é apresentado uma síntese de informações socioeconômicas do município de São Lourenço do Oeste.

Tabela 3- Informações socioeconômicas de São Lourenço do Oeste-SC

\begin{tabular}{|c|c|c|}
\hline Data de emancipação & \multicolumn{2}{|c|}{26 de julho de 1958} \\
\hline Área & \multicolumn{2}{|c|}{$356.193 \mathrm{~km}^{2}$} \\
\hline População & $21.792(2010)$ & $24.291(2020)$ \\
\hline Percentual população rural & \multicolumn{2}{|c|}{$22,54(2010)$} \\
\hline IFDM & $0,7861(2006)$ & $0,8482(2016)$ \\
\hline Ranking IFDM & $288^{\circ}$ Brasil e $32^{\circ} \mathrm{SC}$ & $86^{\circ}$ Brasil e $7^{\circ} \mathrm{SC}$ \\
\hline PIB em mil reais & $493.945(2006)$ & $839.371(2017)$ \\
\hline $\begin{array}{l}\text { Participação do PIB no PIB da microrregião } \\
\text { e do Estado }\end{array}$ & 4,71 e 0,29 (2006) & 5,0 e $0,30(2017)$ \\
\hline $\begin{array}{l}\text { Participação VAB agropecuária, indústria, } \\
\text { serviços, administração pública }\end{array}$ & $\begin{array}{l}11,56 ; 31,18 ; \\
42,69 ; 14,57(2006)\end{array}$ & $\begin{array}{l}7,28 ; 32,5,45,77 \\
14,45(2018)\end{array}$ \\
\hline PIB per capita & \multicolumn{2}{|c|}{$40.274,72(2018)$} \\
\hline Salário médio dos trabalhadores formais & \multicolumn{2}{|c|}{ 2,5 salários (2018) } \\
\hline Taxa de mortalidade infantil & $9,20(2006)$ & $9,68(2017)$ \\
\hline Esperança de vida & $72,68(2000)$ & $73,43(2010)$ \\
\hline Razão de dependência & $53,53(2000)$ & $43,63(2010)$ \\
\hline Taxa de fecundidade & $2,41(2000)$ & $1,69(2010)$ \\
\hline Taxa de analfabetismo & $9,4(2000)$ & $4,9(2010)$ \\
\hline IDEB anos iniciais & $3,9(2005)$ & $7,0(2019)$ \\
\hline IDEB anos finais & $4,3(2005)$ & $5,2(2019)$ \\
\hline IDEB ensino médio & $3,4(2017)$ & $3,9(2019)$ \\
\hline
\end{tabular}

Fonte: IBGE, 2010; 2017; 2020. FIRJAN, 2020 e INEP, 2020.

Nota: PIB deflacionado com base INPC a preços de 2017.

Para complementar a análise demográfica dos três municípios, na Figura 2 é apresentado as pirâmides etárias.

O comportamento da pirâmide etária dos três municípios indica um predomínio de mulheres e uma pirâmide decrescente, onde a base (pessoas jovens) é mais estreita que a classe de adultos (corpo) e o ápice está numa tendência de 


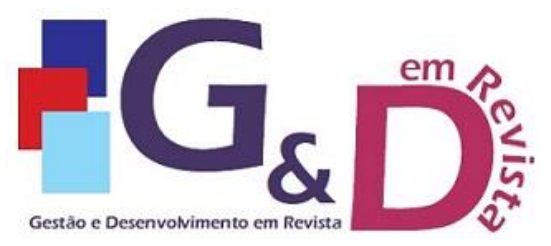

Gestão e Desenvolvimento em Revista V. 8, N. 2, jul-dez/2021, p. 42-67.

ISSN online: $2446-8738$

Artigo recebido em: 21/10/2021

Artigo aprovado em: 12/11/2021

alargamento. Esse comportamento acompanha o comportamento da pirâmide etária brasileira e também de muitos outros países como Dinamarca, Cuba, Peru, Itália, entre outros. A queda na taxa de mortalidade e o aumento da expectativa de vida são os responsáveis por esse comportamento, indicando um avanço social. Apesar disso, é preciso ter atenção e elaborar política públicas para atender a população, pois esse comportamento indica déficit no sistema previdenciário e maior demanda por serviços que atendam a população cada vez mais envelhecida.

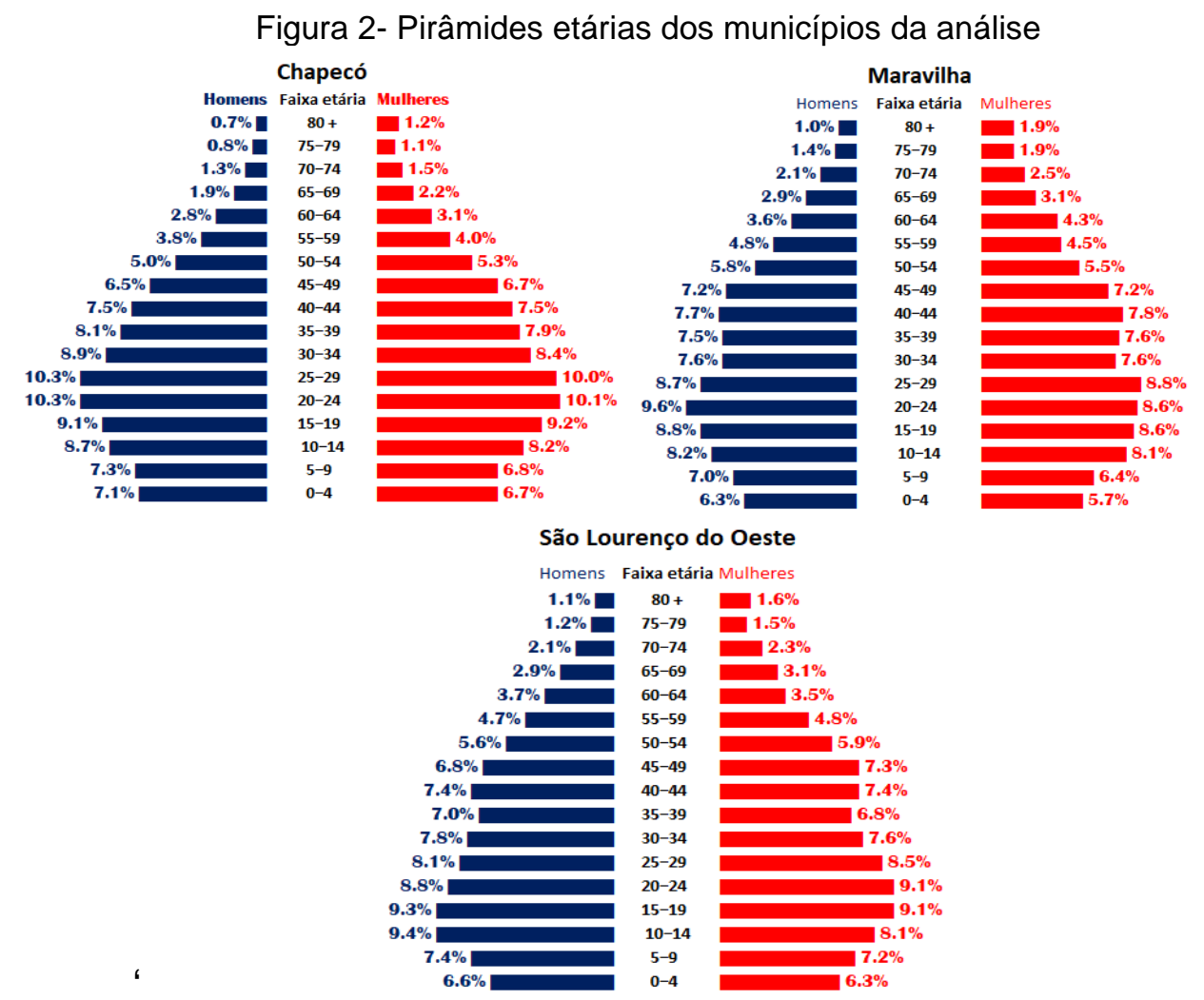

Fonte: Elaborado pela autora com base Censo Demográfico, 2010.

\section{CARACTERIZAÇÃO DOS ESTALECIMENTOS AGROPECUÁRIOS}

Os três municípios analisados apresentaram redução no número de estabelecimentos agropecuários de 2006 para 2017, sendo a maior redução registrada em Chapecó (246 estabelecimentos), representando queda de 13\% conforme mostra a Tabela 4. Os estabelecimentos familiares também se reduziram. Em números absolutos Chapecó teve a maior redução (313) e em números relativos São Lourenço do Oeste (8,9\%). A área total dos estabelecimentos familiares também se reduziu. Esses dados refletem a tendência nacional de êxodo do 
pequeno produtor rural, muito em virtude dos problemas em gerar renda suficiente para o sustento da família.

Kiyota e Perondi (2014) apontam alguns dos fatores que influenciam na permanência dos jovens no campo. Além das condições socioeconômicas, citam o tipo de trabalho realizado, oportunidades de trabalho no campo e cidade (no caso da migração das mulheres vinculam-se principalmente no setor de serviços em expansão), educação, acesso e tipo de lazer, participação em movimentos sociais, trabalho remunerado na propriedade e autonomia na tomada de decisões, perspectiva matrimonial, a diferença no tratamento dos filhos de acordo com o sexo, acesso a crédito, entre outros.

Tabela 4- Número de estabelecimentos agropecuários

\begin{tabular}{|c|c|c|c|c|c|c|}
\hline & \multicolumn{2}{|c|}{ Chapecó } & \multicolumn{2}{|c|}{ Maravilha } & \multicolumn{2}{|c|}{$\begin{array}{c}\text { São Lourenço do } \\
\text { Oeste }\end{array}$} \\
\hline & 2006 & 2017 & 2006 & 2017 & 2006 & 2017 \\
\hline Número de estabelecimentos & 1907 & 1661 & 1003 & 884 & 1447 & 1270 \\
\hline $\begin{array}{l}\text { Percentual de } \\
\text { estabelecimentos agricultura } \\
\text { familiar }\end{array}$ & 84,7 & 78,4 & 89,1 & 81,9 & 91,3 & 82,4 \\
\hline $\begin{array}{l}\text { Área total estabelecimentos } \\
\text { (ha) }\end{array}$ & 34.078 & 30.710 & 14.106 & 13.592 & 29.091 & 28.470 \\
\hline $\begin{array}{l}\text { Percentual área agricultura } \\
\text { familiar }\end{array}$ & 51,8 & 48,3 & 83,3 & 73,4 & 76,9 & 67,8 \\
\hline $\begin{array}{l}\text { Percentual de } \\
\text { estabelecimentos com área de } \\
\text { até } 10 \text { ha }\end{array}$ & 55,0 & 61,3 & 45,6 & 51,7 & 34,2 & 35,3 \\
\hline $\begin{array}{l}\text { Percentual de } \\
\text { estabelecimentos com área de } \\
10 \text { até } 20 \text { ha }\end{array}$ & 19,7 & 19,3 & 32,3 & 26,4 & 33,3 & 30,3 \\
\hline $\begin{array}{l}\text { Percentual de } \\
\text { estabelecimentos com área de } \\
20 \text { até } 100 \text { ha }\end{array}$ & 18,0 & 16,4 & 19,9 & 20,1 & 30,7 & 31,8 \\
\hline $\begin{array}{l}\text { Percentual de } \\
\text { estabelecimentos com área } \\
\text { acima de } 100 \text { ha }\end{array}$ & 2,8 & 3,0 & 0,7 & 1,6 & 1,2 & 2,5 \\
\hline
\end{tabular}

Fonte: resultados da pesquisa.

Prevalece em Chapecó, Maravilha e em São Lourenço do Oeste estabelecimentos com área de até 10 há, com percentual crescente no período, fruto do processo de colonização da região. São Lourenço do Oeste apresenta percentual mais homogêneo de estabelecimentos de 10 ha, 10 a 20 ha e 20 a 100 ha, todos em torno de $30 \%$. Os estabelecimentos com área acima de 100 ha aumentaram nos 3 municípios.

$\mathrm{Na}$ Tabela 5 é apresentado o valor da produção dos estabelecimentos agropecuários deflacionado com base no INPC a preços de 2017. O valor da 
produção se reduziu do ano de 2006 para 2017 em Chapecó e Maravilha e aumentou em São Lourenço do Oeste. A participação da agricultura familiar no valor da produção caiu, com exceção de Chapecó, com considerável aumento. Nesse município a agricultura familiar representou $78,4 \%$ dos estabelecimentos e somente 48,7\% do valor da produção em 2017.

Tabela 5- Valor da produção dos estabelecimentos agropecuários

\begin{tabular}{|c|c|c|c|c|c|c|}
\hline & \multicolumn{2}{|c|}{ Chapecó } & \multicolumn{2}{|c|}{ Maravilha } & \multicolumn{2}{|c|}{$\begin{array}{c}\text { São Lourenço do } \\
\text { Oeste }\end{array}$} \\
\hline & 2006 & 2017 & 2006 & 2017 & 2006 & 2017 \\
\hline $\begin{array}{l}\text { Valor da produção dos } \\
\text { estabelecimentos }\end{array}$ & 405.878 & 152.854 & 97.361 & 72.572 & 60.281 & 96.556 \\
\hline $\begin{array}{l}\text { Percentual da produção } \\
\text { agricultura familiar }\end{array}$ & 24,4 & 48,7 & 88,4 & 79,4 & 89,2 & 82,1 \\
\hline $\begin{array}{l}\text { Percentual da produção } \\
\text { estabelecimentos de até } 10 \text { ha }\end{array}$ & 8,2 & 21,4 & 37,2 & 19,7 & 18,5 & 9,5 \\
\hline $\begin{array}{l}\text { Percentual da produção } \\
\text { estabelecimentos de } 10 \text { até } 20 \\
\text { ha }\end{array}$ & 9,7 & 15,2 & 28,5 & 26,5 & 28,3 & 23,1 \\
\hline $\begin{array}{l}\text { Percentual da produção } \\
\text { estabelecimentos de } 20 \text { até } \\
100 \text { ha }\end{array}$ & 71,2 & 31,9 & 30,9 & 42,5 & 49,6 & 54,9 \\
\hline $\begin{array}{l}\text { Percentual da produção } \\
\text { estabelecimentos acima de } \\
100 \text { ha }\end{array}$ & 10,6 & 24,5 & 1,8 & 10,2 & 3,5 & 12,4 \\
\hline $\begin{array}{l}\text { Valor produção lavouras } \\
\text { temporárias }\end{array}$ & 20.086 & 43.576 & 63.808 & 28.486 & 26.209 & 19.337 \\
\hline $\begin{array}{l}\text { Valor produção lavouras } \\
\text { permanentes }\end{array}$ & 5.276 & 4.023 & 4.054 & 131 & 586 & 117 \\
\hline $\begin{array}{l}\text { Valor produção horticultura e } \\
\text { floricultura }\end{array}$ & 3.674 & 10.666 & 681 & 1.183 & 964 & 1.347 \\
\hline Valor produção pecuária & 366.770 & 86.771 & 28.621 & 41.760 & 31.903 & 70.973 \\
\hline $\begin{array}{l}\text { Valor da produção de leite de } \\
\text { vaca }\end{array}$ & 16.362 & 31.474 & 8.237 & 23.280 & 16.089 & 46.715 \\
\hline $\begin{array}{l}\text { Quantidade produzida de leite } \\
\text { de vaca }\end{array}$ & 20.100 & 28.226 & 11.145 & 21.542 & 21.149 & 43.436 \\
\hline Valor produção florestal & 9.017 & 6.518 & 93 & 538 & 318 & 1.556 \\
\hline
\end{tabular}

Fonte: resultados da pesquisa.

Em Chapecó os estabelecimentos de até 10 ha responderam por $61,3 \%$ dos estabelecimentos do município e apenas $21,4 \%$ do valor da produção em 2017 . Em Maravilha os estabelecimentos de até 10 ha representavam 51,7\% do total do município em 2017 e participaram com 19,7\% do valor da produção. Em São Lourenço do Oeste esses estabelecimentos representavam 35,3\% do total de estabelecimentos e responderam por $9,5 \%$ da produção. Apesar dos pequenos produtores catarinenses estarem integrados as modernas cadeias produtivas, esses números refletem ainda a problemática dos pequenos proprietários em gerar renda. Esse público precisa de atenção dos gestores públicos para que se sustentem na 
atividade rural. Pode existir ainda dificuldade de muitos para acessarem crédito, tecnologia e assistência técnica.

Os estabelecimentos agropecuários acima de 100 ha responderam por 3,0\% do total de estabelecimentos em Chapecó e foram responsáveis por $24,5 \%$ do valor da produção. Em Maravilha eles representavam 1,6\% e foram responsáveis por 10,2\%. Em São Lourenço do Oeste eram 2,5\% e responderam por $12,4 \%$ do valor da produção. Os estabelecimentos dessa faixa de área aumentaram consideravelmente a participação no valor da produção de 2006 para 2017 nos três municípios, com maior aumento para Maravilha. $O$ fator escala e aumento de produtividade com o uso de técnicas e insumos modernos pode ser uma explicação para esse resultado.

O valor da produção das lavouras temporárias se reduziu em Maravilha e em São Lourenço do Oeste, mas em São Lourenço do Oeste a queda foi menor. A produção de horticultura e floricultura é mais expressiva em Chapecó, com significativo aumento de 2006 para 2017.

Para os 3 municípios, em 2017, o maior valor da produção foi encontrado na pecuária. O Estado de Santa Catarina, e principalmente a mesorregião Oeste, foi destaque no cenário nacional na criação de suínos e frangos, com características de integração, e os municípios da análise refletem esse cenário. Chapecó teve redução considerável na atividade, o que pode explicar é que o município vem crescendo na agroindustrialização desses produtos, recebendo as matérias primas da região. Dentro da pecuária, a atividade leiteira também é destaque e vem crescendo nos municípios, com criação de diversos lacticínios nos últimos anos. São Lourenço do Oeste é destaque e apresentou o maior valor da produção e de litros de leite produzidos, tendo aumento considerável de 2006 para 2017. A quantidade produzida de leite de vaca mais que dobrou nesse período.

No geral, os agricultores possuem a propriedade das terras, embora o percentual de Chapecó se reduziu conforme aponta a Tabela 6. Nesse município a condição de produtor assentado teve significativo aumento. Produtor assentado significa que suas terras foram concedidas por órgão fundiário e o produtor ainda não possui título definido, mas ocupa. A categoria arrendatário, aquela em que o pagamento pela utilização é combinado previamente, teve aumento em Maravilha e redução em São Lourenço do Oeste. Na categoria parceiro, o pagamento pelo uso 
da terra é feita com parte da produção. Essa categoria teve significativo aumento em Chapecó e Maravilha. Os ocupantes utilizam a terra de terceiros e nada pagam pelo uso, e exploram mediante ocupação. Essa categoria teve expressivo aumento em São Lourenço do Oeste e redução nos demais. A categoria produtor sem área (aquele que trabalha na área de um terceiro que permite sua utilização) praticamente desapareceu nos três municípios.

Tabela 6- Percentual de estabelecimentos de acordo com condição do produtor

\begin{tabular}{c|c|c|c|c|r|r} 
& \multicolumn{2}{c}{ Chapecó } & \multicolumn{2}{c|}{ Maravilha } & \multicolumn{2}{c}{$\begin{array}{c}\text { São Lourenço do } \\
\text { Oeste }\end{array}$} \\
\cline { 2 - 7 } & $\mathbf{2 0 0 6}$ & $\mathbf{2 0 1 7}$ & $\mathbf{2 0 0 6}$ & $\mathbf{2 0 1 7}$ & $\mathbf{2 0 0 6}$ & $\mathbf{2 0 1 7}$ \\
\hline Proprietário & 87,4 & 81,5 & 89,9 & 91,0 & 92,7 & 92,7 \\
\hline Assentado & 0,4 & 9,5 & 0,2 & 0,1 & 0,2 & 0,1 \\
\hline Arrendatário & 2,7 & 2,7 & 3,9 & 4,4 & 3,7 & 1,9 \\
\hline Parceiro & 1,7 & 3,2 & 1,0 & 2,6 & 0,4 & 0,4 \\
\hline Ocupante & 3,4 & 3,1 & 3,6 & 1,7 & 2,3 & 5,0 \\
\hline $\begin{array}{c}\text { Produtor sem } \\
\text { área }\end{array}$ & 4,4 & 0,0 & 1,4 & 0,2 & & 0,6 \\
\hline
\end{tabular}

Fonte: resultados da pesquisa.

Na Tabela 7 é apresentada a composição do valor da produção da lavoura temporária de Chapecó, Maravilha e São Lourenço do Oeste em relação a produção total da lavoura temporária de cada município, bem como a produtividade da terra das principais culturas, obtida através da divisão da quantidade produzida em tonelada de cada cultura pela área colhida em ha.

Tabela 7- Composição lavoura temporária e produtividade

\begin{tabular}{|c|c|c|c|c|c|c|}
\hline \multirow[t]{2}{*}{ Culturas } & \multicolumn{2}{|c|}{ Chapecó } & \multicolumn{2}{|c|}{ Maravilha } & \multicolumn{2}{|c|}{$\begin{array}{c}\text { São Lourenço do } \\
\text { Oeste }\end{array}$} \\
\hline & 2006 & 2017 & 2006 & 2017 & 2006 & 2017 \\
\hline Soja (\%) & 26,77 & 41,0 & 7,53 & 31,3 & 9,13 & 39,9 \\
\hline Produtividade & 2,5 & 3,4 & 2,4 & 3,3 & 2,5 & 3,2 \\
\hline Milho em grão (\%) & 30,37 & 20,3 & 54,48 & 36,5 & 46,06 & 36,4 \\
\hline Produtividade & 4,3 & 7,2 & 5,7 & 8,7 & 3,5 & 6,5 \\
\hline Milho forrageiro (\%) & 12,56 & 8,7 & 18,17 & 11,9 & 9,02 & 18,5 \\
\hline Produtividade & 20,1 & 28,7 & 29,5 & 44,9 & 20,0 & 30,9 \\
\hline Mandioca (\%) & 7,12 & 12,8 & 1,83 & 1,6 & 30,24 & 1,0 \\
\hline Produtividade & 10,5 & 13,7 & 9,8 & 8,4 & 24,8 & 10,3 \\
\hline Trigo (\%) & 5,28 & 2,3 & 2,11 & 5,2 & 0,39 & 1,5 \\
\hline Produtividade & 1,8 & 2,7 & 1,9 & 3,4 & 1,6 & 2,8 \\
\hline Fumo (\%) & 8,43 & 1,6 & 12,45 & 9,9 & 2,32 & 0,7 \\
\hline Produtividade & 1,8 & 2,0 & 1,9 & 1,9 & 1,3 & 2,1 \\
\hline Feijão preto (\%) & 1,5 & 3,5 & 2,03 & 1,8 & 1,11 & 1,2 \\
\hline Produtividade & 1,2 & 1,6 & 1,8 & 1,2 & 1,2 & 1,8 \\
\hline
\end{tabular}

Fonte: resultados da pesquisa. 
A principal cultura temporária do município de Chapecó em 2006 foi o milho em grãos e em segundo lugar a soja. A soja teve um grande salto de valor da produção de 2006 para 2017, aumentando $14,2 \%$, passando a ser o principal produto da lavoura temporária em 2017. O valor da produção de outras culturas foi reduzindo, principalmente milho, e aumentando a soja, com exceção da mandioca e fumo que registraram aumento. Em relação a área colhida, a soja aumentou em 2.243 ha.

A soja vem ganhando cada vez mais importância devido aos diversos usos e a demanda crescente da China. No período de 2012/2013 a 2018/2019 a produção brasileira cresceu em 35 milhões de toneladas. A principal commodity brasileira vem se consolidando pela introdução cada vez maior de tecnologia, pesquisa e assistência técnica. Esse aumento brasileiro se deu em função do aumento de área e de produtividade. Esse cenário é refletido também nos municípios foco da análise, onde a maior parte do aumento da quantidade produzida se deu pelo aumento da área. Segundo dados da pesquisa, a quantidade produzida aumentou $176,5 \% \mathrm{em}$ Maravilha, 232,4\% em Chapecó e 362,9\% em São Lourenço do Oeste de 2006 a 2017. A produtividade da soja aumentou $28 \%$ em São Lourenço do Oeste, $36 \%$ em Chapecó e 37,5\% em Maravilha e a área colhida aumentou 130,8\% em Maravilha, 165,7\% em Chapecó e 277,9\% em São Lourenço do Oeste (EPAGRI/CEPA, 2020).

As únicas outras culturas em que a área colhida aumentou foi feijão preto (200 ha) e mandioca (93 ha) no município de Chapecó. Todas as culturas de Chapecó tiveram melhora na produtividade, destaque para o milho forrageiro, mandioca e milho em grão. A produtividade do milho em grão nos três municípios da análise em 2017 superam a produtividade do nacional que foi de 5 t/ha (EPAGRI/CEPA, 2020).

Em Maravilha, o milho em grão foi a principal cultura em 2006, com mais da metade do valor da produção, e em seguida milho forrageiro e fumo. Em 2017 o milho em grão continuou sendo a principal cultura, mas com queda na participação no valor da produção e com redução de aproximadamente 11 mil ha. Milho forrageiro e fumo também reduziram o valor da produção e a soja teve um crescimento significativo. A área colhida de trigo e soja foram as únicas culturas com aumento, destaque para soja, 732 ha. A produtividade (quantidade produzida/área 
colhida) do milho forrageiro de Maravilha supera a produtividade do estado de Santa Catarina (37,6t/ha) e do Brasil (28,3t/ha).

Em São Lourenço do Oeste se percebeu resultados contrários, assim como em Chapecó. O milho em grão era a principal cultura em 2006 passando a ser a soja em 2017, com aumento de 30\% na participação no valor da produção e quase 3 vezes mais na área colhida. O milho em grão continua com participação expressiva, mas teve redução de área colhida. O milho forrageiro teve um crescimento considerável em participação no valor da produção e em área colhida, aumentou em mais de 2100 ha. Isso se deu em função de ser uma cultura utilizada na alimentação bovina e São Lourenço do Oeste aumentou muito a quantidade de leite produzida no período.

Destaque também no município de São Lourenço do Oeste é a mandioca, que reduziu mais de $28 \%$ a participação no valor da produção no período, além de reduzir a produtividade. A área colhida de mandioca em 2006 era 1327 ha e em 2017 passou para 16 ha. A queda da produção de mandioca também é uma realidade no estado de Santa Catarina como um todo, se reduzindo desde a safra de 2014, quando os preços caíram muito. Entre 2014 e 2017 houve redução de cerca de $23 \%$ na área cultivada de mandioca. O avanço e sucesso do cultivo da soja responde por essa redução. Além disso, o ciclo da mandioca de 12 a 18 meses sai em desvantagem com a soja, que é de 4 meses em média (EPAGRI/CEPA, 2020).

\section{CARACTERIZAÇÃO DO PESSOAL OCUPADO NOS ESTABELECIMENTOS AGROPECUÁRIOS}

Nesta seção é apresentado uma caracterização do pessoal ocupado nos estabelecimentos agropecuários dos municípios catarinenses de Chapecó, Maravilha e São Lourenço do Oeste. A Tabela 8 indica que o número de pessoas ocupadas no meio rural vem se reduzindo nos 3 municípios de 2006 para 2017, em maior número em Chapecó. 
Tabela 8- Pessoal ocupado por sexo e laço de parentesco com o produtor

\begin{tabular}{c|c|c|c|c|c|c} 
& \multicolumn{2}{c}{ Chapecó } & \multicolumn{2}{c|}{ Maravilha } & \multicolumn{2}{c}{$\begin{array}{c}\text { São Lourenço do } \\
\text { Oeste }\end{array}$} \\
\cline { 2 - 7 } & $\mathbf{2 0 0 6}$ & $\mathbf{2 0 1 7}$ & $\mathbf{2 0 0 6}$ & $\mathbf{2 0 1 7}$ & $\mathbf{2 0 0 6}$ & $\mathbf{2 0 1 7}$ \\
\hline Pessoal ocupado & 5943 & 4866 & 3081 & 2179 & 3879 & 3057 \\
\hline Percentual Homens & 59 & 62,4 & 56,5 & 58,7 & 57,9 & 58,9 \\
\hline Percentual Mulheres & 41 & 37,6 & 43,5 & 41,3 & 42,1 & 41,1 \\
\hline $\begin{array}{l}\text { Percentual Ocupados } \\
\text { na agricultura familiar }\end{array}$ & 76,0 & 66,0 & 88,0 & 81,6 & 89,6 & 81,6 \\
\hline $\begin{array}{l}\text { Percentual ocupado } \\
\text { com laço de parentesco }\end{array}$ & 84,3 & 75,5 & 92,8 & 91,1 & 95,0 & 96,6 \\
\hline $\begin{array}{l}\text { Percentual } \\
\text { Permanentes }\end{array}$ & 11,6 & 17,4 & 1,8 & 2,1 & 1,3 & 2,4 \\
\hline Percentual Temporários & 3,0 & 4,9 & 5,9 & 6,5 & 3,4 & 3,8 \\
\hline Percentual Parceiros & 0,4 & 2,3 & 0 & 0,3 & 0,2 & 0,3 \\
\hline
\end{tabular}

Fonte: resultados da pesquisa.

Predominavam no meio de trabalho rural homens, com percentual crescente de 2006 para 2017. Essa é uma tendência também para Santa Catarina e para o Brasil. O predomínio maior era de pessoal ocupado na agricultura familiar em 2006, também com redução no período, sendo em número bem reduzido em Chapecó comparado aos outros dois municípios. Predominavam também pessoas ocupadas que faziam parte da família do produtor rural. Entre os ocupados sem laço de parentesco predominavam trabalhadores permanentes. $O$ percentual de trabalhadores temporários vem crescendo em todos os municípios, apesar do número absoluto ter aumentado apenas em Chapecó.

A Tabela 9 indica que as propriedades rurais no geral, nos três municípios, eram administradas por homens, seguindo a tendência histórica do patriarcalismo no Brasil (ARRAIS; PRAT; CAMBRAIA, 2019). Mas, apesar disso, o percentual se reduziu de 2006 para 2017. A maior redução foi em Chapecó indicando um pequeno avanço conquistado pelas mulheres.

Quanto à faixa etária, os jovens, menores de 25 anos era a minoria no campo, e essa participação se reduziu de 2006 para 2017. Em Chapecó e Maravilha a maioria dos estabelecimentos agropecuários eram dirigidos em 2017 por pessoas com idade entre 55 a 65 anos, sendo pouca diferença para a segunda classe com maior número de dirigentes, a faixa etária de 45 a 55 anos. Esses eram a maioria em 2006. Em São Lourenço do Oeste, assim como em 2006, prevaleceram dirigentes na faixa etária de 45 a 55 anos. Esses dados alertam para o êxodo rural e 
o problema da sucessão familiar, uma vez que a permanência no campo está se efetivando por pessoas mais idosas.

Outra informação interessante é sobre o local de residência dos dirigentes dos estabelecimentos. A maior parte dos dirigentes residia nos estabelecimentos, mas esse número se reduziu de 2006 para 2017. A maior redução foi registrada em Maravilha, mas em São Lourenço do Oeste se registrou o menor percentual (85\%).

Tabela 9- Percentual de estabelecimentos de acordo com classificação do dirigente

\begin{tabular}{l|c|c|c|c|c|c}
\cline { 2 - 7 } & \multicolumn{2}{c}{ Chapecó } & \multicolumn{2}{c|}{ Maravilha } & \multicolumn{2}{c}{$\begin{array}{c}\text { São Lourenço do } \\
\text { Oeste }\end{array}$} \\
\cline { 2 - 7 } & $\mathbf{2 0 0 6}$ & $\mathbf{2 0 1 7}$ & $\mathbf{2 0 0 6}$ & $\mathbf{2 0 1 7}$ & $\mathbf{2 0 0 6}$ & $\mathbf{2 0 1 7}$ \\
\hline $\begin{array}{l}\text { Estabelecimentos dirigidos por } \\
\text { homens }\end{array}$ & 90,5 & 86,4 & 87,7 & 86,8 & 92,1 & 89,3 \\
\hline $\begin{array}{l}\text { Estabelecimentos dirigidos por } \\
\text { mulheres }\end{array}$ & 9,5 & 13,6 & 12,3 & 13,2 & 7,9 & 10,7 \\
\hline $\begin{array}{l}\text { Estabelecimentos dirigidos por } \\
\text { menor 25 anos }\end{array}$ & 2,5 & 1,5 & 1,1 & 0,8 & 1,7 & 0,7 \\
\hline $\begin{array}{l}\text { Estabelecimentos dirigidos por } \\
\text { pessoa de 25 a 35 anos }\end{array}$ & 9,2 & 6,5 & 8,5 & 5,3 & 8,3 & 6,0 \\
\hline $\begin{array}{l}\text { Estabelecimentos dirigidos por } \\
\text { pessoa de 35 a 45 anos }\end{array}$ & 24,0 & 14,4 & 23,9 & 14,3 & 26,2 & 13,9 \\
\hline $\begin{array}{l}\text { Estabelecimentos dirigidos por } \\
\text { pessoa de 45 a 55 anos }\end{array}$ & 28,3 & 26,4 & 28,8 & 29,0 & 28,0 & 29,9 \\
\hline $\begin{array}{l}\text { Estabelecimentos dirigidos por } \\
\text { pessoa de 55 a 65 anos }\end{array}$ & 22,8 & 28,2 & 21,9 & 30,5 & 23,5 & 27,9 \\
\hline $\begin{array}{l}\text { Estabelecimentos dirigidos por } \\
\text { pessoa de 65 a 75 anos }\end{array}$ & 13,2 & 17,0 & 15,8 & 15,5 & 12,3 & 16,6 \\
\hline $\begin{array}{l}\text { Estabelecimentos em que o } \\
\text { dirigente reside no } \\
\text { estabelecimento }\end{array}$ & 92,4 & 89,7 & 96,3 & 89,7 & 91,4 & 85,0 \\
\hline Fonte: resultas da pesquisa & & & &
\end{tabular}

Fonte: resultados da pesquisa.

$\mathrm{Na}$ Tabela 10 é apresentado informações a respeito dos estabelecimentos, se os produtores eram associados em cooperativas e se recebiam orientação técnica. O número de estabelecimentos agropecuários se reduziu no período, assim como o número de estabelecimentos em que o produtor era associado a cooperativas e que recebia orientação técnica em todos os municípios da análise. Em termos percentuais isso também ocorreu, sendo Maravilha onde ocorreu a maior filiação, quase $70 \%$ dos produtores eram associados e $67,2 \%$ dos estabelecimentos o produtor recebia orientação técnica. Destaque se dá para São Lourenço do Oeste em que o percentual de estabelecimentos em que o produtor recebia orientação técnica caiu pela metade de 2006 para 2017.

A orientação técnica recebida pelos produtores de Chapecó e Maravilha em 2017 foi obtida principalmente através das cooperativas e das empresas 
integradoras. Em São Lourenço do Oeste eles receberam primeiramente de cooperativas e em segundo lugar contratadas pelo próprio produtor.

As cooperativas são soluções de desenvolvimento, oportunidades e vantagens para os produtores, especialmente os pequenos e se percebe que ainda existe espaço para crescimento desse setor.

Tabela 10- Informações sobre associação em cooperativas, orientação técnica e escolaridade dos produtores dos estabelecimentos agropecuários

\begin{tabular}{l|c|c|c|c|c|c}
\cline { 2 - 7 } \% de estabelecimentos & \multicolumn{2}{c|}{ Chapecó } & \multicolumn{2}{c|}{ Maravilha } & \multicolumn{2}{c}{$\begin{array}{c}\text { São Lourenço do } \\
\text { Oeste }\end{array}$} \\
\cline { 2 - 8 } & $\mathbf{2 0 0 6}$ & $\mathbf{2 0 1 7}$ & $\mathbf{2 0 0 6}$ & $\mathbf{2 0 1 7}$ & $\mathbf{2 0 0 6}$ & $\mathbf{2 0 1 7}$ \\
\hline $\begin{array}{l}\text { Em que o produtor é associado a } \\
\text { cooperativa ou entidade de classe }\end{array}$ & 49,1 & 45,0 & 75,1 & 69,3 & 53,4 & 52,8 \\
\hline $\begin{array}{l}\text { Em que o produtor recebe orientação } \\
\text { técnica }\end{array}$ & 45,6 & 38,9 & 68,4 & 67,2 & 36,2 & 17,1 \\
\hline $\begin{array}{l}\text { Em que o produtor não sabe ler e } \\
\text { escrever }\end{array}$ & 5,3 & 7,8 & 2,1 & 2,1 & 2,4 & 3,1 \\
\hline Em o produtor nunca frequentou escola & - & 5,1 & - & 1,4 & - & 3,6 \\
\hline $\begin{array}{l}\text { Em que o produtor estudou apenas a } \\
\text { alfabetização }\end{array}$ & 1,7 & 4,8 & 1,5 & 2,9 & 1,6 & 0,8 \\
\hline $\begin{array}{l}\text { Em que o produtor estudou até o } \\
\text { ensino fundamental }\end{array}$ & 71,7 & 67,0 & 88,4 & 74,2 & 87,5 & 76,5 \\
\hline $\begin{array}{l}\text { Em que o produtor estudou até o } \\
\text { ensino médio }\end{array}$ & 10,7 & 16,3 & 6,0 & 16,2 & 5,3 & 13,7 \\
\hline $\begin{array}{l}\text { Em que o produtor estudou até o } \\
\text { ensino superior }\end{array}$ & 4,8 & 5,5 & 1,5 & 5,1 & 1,9 & 4,5 \\
\hline $\begin{array}{l}\text { Em que o produtor estudou até o } \\
\text { mestrado/doutorado }\end{array}$ & - & 0,5 & - & 0 & - & 0,4 \\
\hline Foste: resulados da pesquisa.
\end{tabular}

Fonte: resultados da pesquisa.

A Tabela 10 também apresenta informações sobre a escolaridade dos produtores dos estabelecimentos agropecuários. Muitas dessas informações são imprecisas nos Censos ou não existem (-) para os 2 anos analisados, portanto podem ocorrer divergências nos percentuais. Em números absolutos os estabelecimentos em que o produtor não sabia ler caiu nos três municípios, mas em termos percentuais o número só não cresceu em Maravilha, onde o número também foi o menor dentre os municípios do estudo (19 estabelecimentos).

Dentre os estabelecimentos em que os produtores que não sabiam ler e escrever, a maioria dos responsáveis eram homens, 73,6\% em 2017 em Chapecó, 89,5\% em Maravilha e 87,5\% em São Lourenço do Oeste. Esses números representam ainda que $6,7 \%$ de todos os estabelecimentos em que o produtor era homem, eles não sabiam ler em Chapecó, 2,2\% em Maravilha e 3,1\% em Chapecó. 
Prevaleceu nos 3 municípios produtores rurais que estudaram apenas até 0 ensino fundamental (aqui completo ou incompleto). Esse número se reduziu e aumentou o percentual de estabelecimentos em que o produtor estudou até o ensino médio, o que é positivo indicando aumento da escolaridade dos produtores rurais. Apesar disso, o percentual de estabelecimentos em que o produtor foi apenas alfabetizado aumentou em Chapecó e em Maravilha, e em Chapecó em maior número.

O grau de instrução dos produtores é muito relevante, pois interfere na facilidade de obtenção e processamento de informações, bem como a maneira correta de utilizar essas informações para o processo produtivo. Um produtor com maior grau de instrução consegue gerir a propriedade de forma mais segura e assertiva (ARRAIS; PRAT; CAMBRAIA, 2019).

Destaque positivo se dá para a classe dos estabelecimentos em que o produtor rural estudou até o ensino superior que vem crescendo nos três municípios. Os maiores crescimentos foram em Maravilha, 15 para 45 estabelecimentos, e São Lourenço do Oeste, de 28 para 57 estabelecimentos.

\section{CONSIDERAÇÕES FINAIS}

O trabalho objetivou caracterizar os estabelecimentos agropecuários e a população ocupada dos 3 principais municípios da microrregião de Chapecó- SC, sendo eles Chapecó, Maravilha e São Lourenço do Oeste, a partir de uma análise comparativa realizada com os dados disponíveis nos Censos Agropecuários de 2006 e 2017.

A microrregião de Chapecó é uma das mais importantes do Estado, participou com $17,30 \%$ da produção de suínos, $21,60 \%$ das aves produzidas, $18,35 \%$ da produção de milho, $20,8 \%$ de trigo e $10,7 \%$ de soja do estado no ano de 2017. Os municípios escolhidos se destacam em população e produção agropecuária (IBGE, 2017; EPAGRI/CEPA, 2020).

Os três municípios apresentaram redução no número de estabelecimentos agropecuários e de população ocupada de 2006 para 2017, sendo a maior redução registrada por Chapecó. Essa também é uma tendência nacional. Nesses municípios 
prevalece estabelecimentos com 10 ha, indicando a predominância de pequenos estabelecimentos, fruto do processo de colonização da região Oeste catarinense.

Em Chapecó os estabelecimentos de até 10 ha representavam 61,3\% total e respondiam apenas por $21,4 \%$ do valor da produção em 2017. Em Maravilha eles representavam 51,7\% em 2017 e participaram com 19,7\% do valor da produção. Em São Lourenço do Oeste esses estabelecimentos representavam 35,3\% e responderam por $9,5 \%$ da produção. Ou seja, os estabelecimentos de pequenos produtores são a maioria, mas não respondem pela maioria do valor da produção gerado. Esses números indicam a necessidade de políticas públicas no meio rural para gerar outras soluções de renda aos pequenos proprietários e para garantia da manutenção dessa população no campo.

Esses dados levantam o questionamento do por quê isso vem acontecendo. Dificuldade de acessar tecnologia e crédito, falta de assistência técnica, baixa escolaridade podem ser as respostas. Algumas possíveis soluções podem ser apontadas. Alternativas para os pequenos produtores captarem um maior valor do que produz, reduzindo intermediários através de cadeias curtas, como feiras e vendas diretas. Investimento em agroindústrias, criação de nichos de mercado como orgânicos e a pluriatividade como o agroturismo. Para fomentar todas essas atividades a cooperação se torna primordial assim como o apoio e incentivo do poder púbico. Analisar essas relações e possíveis soluções é uma indicação de trabalhos futuros.

A maioria dos produtores rurais eram proprietários das terras em que trabalhavam e eram os homens que mais dirigiam os estabelecimentos. Prevaleceu produtores familiares, também conforme tendência do país. Predominavam dentre as pessoas ocupadas as que faziam parte da família do produtor rural. Entre os ocupados sem laço de parentesco predominavam trabalhadores permanentes. $O$ percentual de trabalhadores temporários cresceu em todos os municípios, apesar do número absoluto ter aumentado apenas em Chapecó.

Jovens menores de 25 anos são a minoria no campo, e essa participação vem reduzindo de 2006 para 2017. Em Chapecó e Maravilha a maioria dos estabelecimentos agropecuários eram dirigidos em 2017 por pessoas com idade entre 55 a 65 anos. Os dirigentes a faixa etária de 45 a 55 anos eram a maioria em 2006. Em São Lourenço do Oeste em 2017, assim como em 2006, prevaleceu 
dirigentes na faixa etária de 45 a 55 anos. Esses dados alertam para o êxodo rural e o problema da sucessão familiar, uma vez que a permanência no campo está se efetivando por pessoas mais idosas.

Maiores conhecimentos e escolarização dos produtores rurais facilita 0 processo de gestão mais assertiva da propriedade. Em números absolutos os estabelecimentos em que o produtor não sabe ler vem caindo nos três municípios, mas em termos percentuais o número só não cresceu em Maravilha, onde o número também é o menor dentre os municípios do estudo.

Prevaleceu nos 3 municípios produtores rurais que estudaram apenas até o ensino fundamental (completo ou incompleto), e esse número se reduziu e aumentou o percentual de estabelecimentos em que o produtor estudou até o ensino médio, o que é positivo indicando aumento da escolaridade dos produtores rurais, mas ainda indica que muito precisa ser feito em prol dos produtores rurais.

Algumas limitações podem ser apontadas para construção do trabalho principalmente porque alguns dados apresentaram inconsistências nas contagens quando desmembrados. Não se pretende esgotar os estudos a respeito da temática, que pode ser estendida a outras localidades.

\section{REFERÊNCIAS}

ALVES, P. A.; MATTEI, L. F. Migrações no oeste catarinense: História e elementos explicativos. In: ENCONTRO NACIONAL DE ESTUDOS POPULACIONAIS- ABEP, 15, Caxambú- MG, 2006. Anais eletrônicos [...]. Caxambú: ABEP, 2006, p. 1-20.

ARRAIS, S. C. da S.; PRAT, B. V.; CAMBRAIA, R. P. Análise dos Censos Agropecuários Brasileiros dos Anos de 2006 e 2017 para Identificação de Características da População Agrícola. Revista Cerrados, v. 17, n. 02, p. 228-246, 2019.

BACHA, C.J.C. Economia e política agrícola no Brasil. 2 ed. São Paulo, Atlas, 2012.

BUAINAIN, A. M. Alguns condicionantes do novo padrão de acumulação da agricultura brasileira. In: BUAINAIN, A. M.; ALVES, E.; SILVEIRA, J. M. da; NAVARRO, Z. (Ed.). O mundo rural no Brasil do século 21: a formação de um novo padrão agrário e agrícola. Brasília, DF: Embrapa, pg. 211-240, 2014.

BUAINAIN, A. M.; PEDROSO, M. T. M.; VIEIRA JÚNIOR, P. A.; SILVEIRA, R. L. F. da; NAVARRO, Z. Quais os riscos mais relevantes nas atividades agropecuárias? In: 


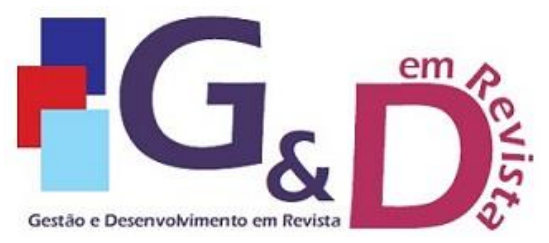

Gestão e Desenvolvimento em Revista V. 8, N. 2, jul-dez/2021, p. 42-67. ISSN online: $2446-8738$ Artigo recebido em: 21/10/2021 Artigo aprovado em: 12/11/2021

BUAINAIN, A. M.; ALVES, E.; SILVEIRA, J. M. da; NAVARRO, Z. (Ed.). O mundo rural no Brasil do século 21: a formação de um novo padrão agrário e agrícola. Brasília, DF: Embrapa, pg. 175-208, 2014.

CORRÊA, A. de S.; LIMA, J. F. de. Modernização da agricultura e os ciclos de produção extensiva e intensiva em Mato Grosso do Sul: impactos na ocupação da mão de obra agrícola (1970-2014). CAMPO-TERRITÓRIO: revista de geografia agrária, v. 11, n. 24 Ago., 2016.

DENTZ, E. V. Estrutura econômico-produtiva e a dinâmica urbana regional de Chapecó- SC, Brasil. In: ENAMPEGE, 13, SÃO PAULO, 2019. Anais eletrônicos [...]. São Paulo: ENAMPEGE, 2019. Disponível em: <https://www.enanpege2019.anpege.ggf.br/resources/anais/8/1561410979 ARQUIV O ArtigoFinal Enanpege2019.pdf>. Acesso em: 15 dez. 2020.

\section{EPAGRI/CEPA. Síntese anual da agricultura de Santa Catarina 2018-2019.} Florianópolis: Epagri/Cepa, 2020.

FIRJAN. Índice Firjan de Desenvolvimento Municipal (IFDM). Disponível em: <https://www.firjan.com.br/ifdm/>. Acesso em: 25 nov. 2020.

FRIESTINO, J. K. O.; BALDISSERA, V. G.; SANTOS, V. H. B. Saúde, Ambiente e Desenvolvimento nas Microrregiões de Chapecó-SC e Erechim-RS. Hygeia-Revista Brasileira de Geografia Médica e da Saúde, v. 16, p. 25-36, 2020.

GARCIA, J. R. Trabalho rural: tendências em face das transformações em curso. In: BUAINAIN, A. M.; ALVES, E.; SILVEIRA, J. M. da; NAVARRO, Z. (Ed.). O mundo rural no Brasil do século 21: a formação de um novo padrão agrário e agrícola. Brasília, DF: Embrapa, pg. 560-589, 2014.

GEREI, N. M. H. Presença da cultura italiana no município de Maravilha/SC: crenças e atitudes. RELACult-Revista Latino-Americana de Estudos em Cultura e Sociedade, v. 5, n. 5, 2019.

IBGE. Censo Agropecuário 2006. Segunda apuração. Disponível em: $<$ https://sidra.ibge.gov.br/pesquisa/censo-agropecuario/censo-agropecuario2006/segunda-apuracao>. Acesso em: 25 nov. 2020.

IBGE. Censo Demográfico 2010. Caracterização da População e dos Domicílios. Disponível em: https://sidra.ibge.gov.br/pesquisa/censo-demografico/demografico2010/universo-caracteristicas-da-populacao-e-dos-domicilios. Acesso em: 25 nov. 2020.

IBGE. Censo Agropecuário 2017. Resultados Definitivos. Disponível em: $<$ https://sidra.ibge.gov.br/pesquisa/censo-agropecuario/censo-agropecuario-2017>. Acesso em: 25 nov. 2020.

IBGE. Estimativas da população2020. Disponível em: $<$ https://sidra.ibge.gov.br/pesquisa/estimapop/tabelas $>$. Acesso em: 25 nov. 2020. 
INEP. Índice de Desenvolvimento da Educação Básica (IDEB). Disponível em: http://ideb.inep.gov.br/. Acesso em: 25 nov. 2020.

JOCHIMS, F.; DORIGON, C.; PORTES, V. M. O leite para o Oeste Catarinense. Agropecuária Catarinense, v. 29, n. 3, p. 18-21, 2016.

KIYOTA, N.; PERONDI, M. A. Sucessão geracional na agricultura familiar: Uma questão de renda? In: BUAINAIN, A. M.; ALVES, E.; SILVEIRA, J. M. da; NAVARRO, Z. (Ed.). O mundo rural no Brasil do século 21: a formação de um novo padrão agrário e agrícola. Brasília, DF: Embrapa, pg. 1011-1045, 2014.

SANTOS, A. S. dos. A modernização da agricultura no Brasil: transições agrícolas e autogestão. DESAFIOS-Revista Interdisciplinar da Universidade Federal do Tocantins, v. 7, n. 3, p. 209-229, 2020.

SANTOS, L. P. dos; AVELAR, J. M. B.; SHIKIDA, P. F. A.; CARVALHO, M. A. de. Agronegócio Brasileiro no comércio internacional. Revista de Ciências Agrárias, v. 1, n. 39, p. 54-69, 2016.

VARNIER, M. Considerações sobre a teoria dos dois circuitos da economia urbana em Chapecó-SC. Revista Cadernos de Economia, v. 25, n. 41, p. 1-23, 2020. 